\title{
Acid and neutral $\alpha$-glucosidase in the reproductive organs and seminal plasma of the bull
}

\author{
A. Jauhiainen and T. Vanha-Perttula \\ Department of Anatomy, University of Kuopio, P.O. Box 6, 70211 Kuopio, Finland
}

\begin{abstract}
Summary. A synthetic substrate ( $p$-nitrophenyl- $\alpha$-D-glucopyranoside) was used to measure the acid and neutral $\alpha$-glucosidase activity in bull seminal plasma, spermatozoa and in homogenates of bull reproductive organs. Marked differences were observed in the activities of these enzymes in the various tissues studied. Epididymis and particularly its caput region contained the highest specific activity of acid $\alpha-$ glucosidase. The activity of neutral $\alpha$-glucosidase was highest in testis and in different parts of the epididymis. Seminal plasma, spermatozoa and seminal vesicle secretion contained only the acid enzyme activity.

After fractionation with anion exchange chromatography in HPLC (Mono Q) and chromatofocussing, acid $\alpha$-glucosidase activity of seminal plasma was recovered in two fractions with different $p I$ values. The corresponding activities were found in the secretion of seminal vesicles, which thus form the major secretory source of seminal plasma acid $\alpha$-glucosidase. In the fractionation with gel filtration on Sepharose 6B, the acid $\alpha$-glucosidase had a smaller molecular weight than did the neutral enzyme. In anion exchange chromatography and chromatofocussing the testicular and epididymal homogenates each contained two acid and two neutral isoenzymes. In both fractionations the elution pattern of acid $\alpha$-glucosidase was clearly different from that of the enzymes in seminal plasma.

The $\mathrm{pH}$ optimum of acid $\alpha$-glucosidase ranged from 3.75 to 4.5 and that of the neutral enzyme from 6.5 to 7.0 . The neutral activity was more sensitive to many divalent metal ions and differences were also observed in the response of the enzymes to different concentrations of turanose and $\mathrm{KCl}$.
\end{abstract}

\section{Introduction}

$\alpha$-Glucosidases ( $\alpha$-D-glucoside glucohydrolase; EC 3.2.1.20, also known as maltase) catalyse the cleavage of $\alpha$-D-glucose residues from poly- and oligosaccharides. The enzymes of this group are known to differ from each other in their subcellular distribution, types of bonds hydrolysed, $\mathrm{pH}$ optima and many other biochemical characteristics (Rosenfeld, 1975). $\alpha$-Glucosidases can be divided into two major groups: acid $\alpha$-glucosidases with an optimum at pH 4.0-5.0 and neutral $\alpha$ glucosidases with an optimum at $\mathrm{pH} 6 \cdot 0-7 \cdot 0$. The acid enzymes are located in lysosomes while the neutral ones are bound to microsomes or are soluble in cytoplasm (Torres \& Olavarria, 1964; Bruni, Sica, Auricchio \& Covelli, 1970; Michael \& Kornfeld, 1980; Burns \& Touster, 1982).

Sheth \& Rao (1962) first reported $\alpha$-glucosidase (maltase) activity in the seminal plasma of man, cock, bull and rabbit. This enzyme had an acid pH optimum ( $\mathrm{pH} \mathrm{4.5-5.0)} \mathrm{and} \mathrm{was} \mathrm{able} \mathrm{to} \mathrm{cleave}$ glucose from different oligosaccharides. Tissue distribution of this enzyme in rats and mice indicated that dorsal prostate and coagulating gland had the highest activity levels (Gunaga, Sheth \& Rao, 1967). Most of the activity was found in the soluble fraction and in both glands its level was dependent on sexual maturation. More recent studies with the reproductive organs of male rats indicated that both acid and neutral $\alpha$-glucosidase are present (Grandmont, Chapdelaine \& 
Tremblay, 1983). Moreover, the epididymis appeared to have the highest activity levels and among the reproductive organs it showed a clear response to hormone treatment.

$\alpha$-Glucosidase in human seminal plasma also seems to be under hormonal control (Gunaga, Sheth, Rao \& Pardanani, 1971). Studies on fertile, infertile and vasectomized men have indicated that the epididymis is the main source of this enzyme in seminal plasma (Chapdelaine, Tremblay, Dubé, St-Yves \& Mailhot, 1978b; Guerin et al., 1981 ; Rivas et al., 1981; Tremblay, Chapdelaine \& Dubé, 1982a; Tremblay, Chapdelaine, Roy \& Thabet, 1982b; Paquin, Chapdelaine, Dubé \& Tremblay, 1984). Biochemical studies on the $\alpha$-glucosidase of human seminal plasma have disclosed at least two forms of the enzyme, both of which have a neutral $\mathrm{pH}$ optimum (Chapdelaine et al., 1978b; Chapdelaine, Tremblay \& Dubé, 1979; Tremblay et al., 1982a). In contrast to the $\alpha$ glucosidase of human seminal plasma, the activity in ram seminal plasma shows an acid $\mathrm{pH}$ optimum (Besancon, Chapdelaine, Tremblay \& Lemay, 1983), but no information is available concerning the origin of this enzyme.

The purpose of this study was to analyse the activity of $\alpha$-glucosidase in bull seminal plasma and to study the origin of the enzyme activity from the reproductive organs.

\section{Materials and Methods}

Semen and reproductive organs. The semen samples were obtained from mature Finnish Ayrshire bulls by means of an artificial vagina and immediately sent to the laboratory. To separate spermatozoa from seminal plasma, all the samples were centrifuged at $8000 \mathrm{~g}$ for $30 \mathrm{~min}$ at $4^{\circ} \mathrm{C}$ in a Sorvall RC- 5 centrifuge. The spermatozoa were washed twice with $0.025 \mathrm{M}$-imidazole- $\mathrm{HCl}$ buffer, pH 7.4, resuspended in the same buffer and sonicated with an MSE 150 Watt Ultrasonic Disintegrator for $90 \mathrm{sec}$ at $4^{\circ} \mathrm{C}$. The sperm suspensions were then centrifuged at $100000 \mathrm{~g}$ for $1 \mathrm{~h}$ at $4^{\circ} \mathrm{C}$ in an MSE Superspeed 75 centrifuge. The supernatants were used for enzyme determinations.

The reproductive organs of Finnish Ayrshire bulls were obtained from a local abattoir immediately after the slaughter of the animals. The organs (testis, caput, corpus and cauda epididymidis, vas deferens, ampulla, seminal vesicle, prostate and Cowper's glands) were dissected, cleaned of fat and weighed. The fluid within the seminal vesicles was collected into small tubes and centrifuged at $100000 \mathrm{~g}$ for $1 \mathrm{~h}$ at $4^{\circ} \mathrm{C}$. Enzymes were measured in the supernatants.

For studying the enzyme distribution in the epididymis, the organ was divided into six segments $\left(E_{1}-E_{6}\right)$ according to the method of Nicander (1958) (Text-fig. 1). These segments were then weighed and homogenized as described later.

In the attempt to determine the cellular or secretory nature of the enzyme activity, the epididymal segments $E_{1}, E_{2}+E_{3}$ (caput) and $E_{6}$ (cauda) were cut into small pieces in cold $0.9 \%$ $(\mathrm{w} / \mathrm{v}) \mathrm{NaCl}$. After gentle shaking and squeezing the pieces in $\mathrm{NaCl}$ solution, the suspensions were

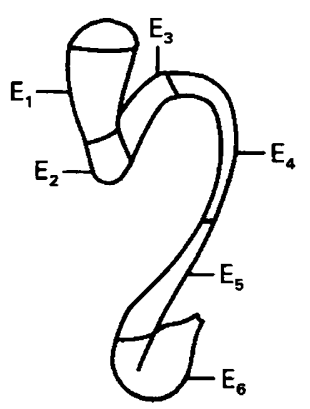

Text-fig. 1. Schematic presentation of the six segments $\left(E_{1}-E_{6}\right)$ of the bull epididymis according to Nicander (1958). 
collected and spermatozoa were pelleted by centrifugation at $1300 \mathrm{~g}$ for $15 \mathrm{~min}$ in a Sorvall GLC-2 centrifuge. The supernatants were recentrifuged at $1300 \mathrm{~g}$ for $15 \mathrm{~min}$ and used for further studies (= epididymal secretions). The suspended spermatozoa were washed twice by centrifugation, resuspended in $\mathrm{NaCl}$ solution, sonicated and centrifuged as described earlier (= epididymal spermatozoa). Phase-contrast microscopy of the latter sample after washings revealed a very pure sperm preparation.

To obtain the 'cellular' (or tissue) compartments of the epididymis, segments $E_{1}, E_{2}+E_{3}$ and $E_{6}$ in $\mathrm{NaCl}$ solution were minced with scissors and centrifuged through a nylon sieve fitting a small conical tube at $1300 \mathrm{~g}$ for $15 \mathrm{~min}$ in a Sorvall GLC-2 centrifuge. The tissue components were then weighed and homogenized as described later ( $=$ epididymal cells).

All the samples were stored at $-80^{\circ} \mathrm{C}$ until used.

Chemicals. The chromogenic substrate ( $p$-nitrophenyl- $\alpha$-D-glucopyranoside), Tris [tris-(hydroxymethyl)aminomethane] and $D(+)$-turanose (3-0- $\alpha$-D-glucopyranosyl-D-fructose) were purchased from Sigma Chemical Company (St Louis, MO, U.S.A.). The reagents and chemicals utilized to separate, measure and characterize $\alpha$-glucosidase were obtained from different sources: Sepharose 6B, Mono Q column, Polybuffer Exchanger PBE 94, Polybuffer 74 and gel filtration calibration kit were from Pharmacia Fine Chemicals (Uppsala, Sweden). Triton X-100 was from BDH Chemicals Ltd (Poole, U.K.). Other chemicals were purchased from E. Merck AG (Darmstadt, West Germany).

Tissue homogenization. The tissues from each animal were minced with scissors and homogenized in $0.02 \mathrm{M}$-sodium acetate, $\mathrm{pH} 7 \cdot 0$, containing $0.1 \%(\mathrm{v} / \mathrm{v})$ Triton $\mathrm{X}-100(200 \mathrm{mg}$ tissue $/ \mathrm{ml}$ buffer for adult and young bulls and $20 \mathrm{mg}$ tissue $/ \mathrm{ml}$ buffer for immature bulls) with a glass homogenizer and power-driven Teflon pestle for 20 strokes. The homogenates were then sonicated in an MSE 150 Watt Ultrasonic Disintegrator for $90 \mathrm{sec}$ at $4^{\circ} \mathrm{C}$ and centrifuged at 50000 $\boldsymbol{g}$ for $1 \mathrm{~h}$ in a Sorvall $\mathrm{RC}-5$ centrifuge. The supernatants were utilized for measuring the enzyme activities and for separating them by gel filtration, chromatofocussing and anion exchange chromatography.

Fractionation. Gel filtration with Sepharose 6B was carried out in a column $(2.6 \times 91 \mathrm{~cm})$ equilibrated with $0 \cdot 02 \mathrm{M}-\mathrm{KH}_{2} \mathrm{PO}_{4}$ buffer, $\mathrm{pH} 7 \cdot 0$, containing $0 \cdot 15 \mathrm{M}-\mathrm{NaCl}$. The samples (3-4 ml) were eluted with the same buffer and fractions of $2.7 \mathrm{ml}$ were collected at $4^{\circ} \mathrm{C}$.

Marker proteins (thyroglobulin, $669 \times 10^{3}$; ferritin, $440 \times 10^{3}$; catalase, $232 \times 10^{3}$; aldolase, $158 \times 10^{3}$; bovine serum albumin, $67 \times 10^{3}$; chymotrypsinogen $\mathrm{A}, 25 \times 10^{3}$ ) for the molecular weight determination were included in the gel filtration with Blue Dextran to indicate the void volume $\left(\mathrm{V}_{0}\right)$.

For chromatofocussing, PBE 94 gel was packed into a column $(0.9 \times 30 \mathrm{~cm})$ equilibrated with $0.025 \mathrm{M}$-imidazole- $\mathrm{HCl}, \mathrm{pH} 7.4$ (initial buffer for chromatofocussing). When the sample (3-4 ml) had been applied, the enzymes were eluted with Polybuffer $74-\mathrm{HCl}, \mathrm{pH} 4 \cdot 0$, according to the instructions of the manufacturer to obtain a gradient for $\mathrm{pH}$ range $7-4$. Fractions of $2.7 \mathrm{ml}$ were collected at $4^{\circ} \mathrm{C}$. After the Polybuffer elution, a $\mathrm{NaCl}$ gradient $(0-0.5 \mathrm{M})$ was formed in $0.02 \mathrm{M}-$ sodium acetate, $\mathrm{pH} 5 \cdot 0$, and $4.0 \mathrm{ml}$ fractions were collected. The $\mathrm{pH}$ of the fractions was measured with a microelectrode and protein by absorbance at $280 \mathrm{~nm}$.

The high-performance liquid chromatography (HPLC) on Mono $Q$, a prepacked anion exchanger, was carried out with $0.02 \mathrm{M}-\mathrm{KH}_{2} \mathrm{PO}_{4}$ buffer, $\mathrm{pH} 7.0$, and a $\mathrm{NaCl}$ gradient (0-0.5 M). The HPLC system consisted of an Altex 240 microprocessor controller/programmer equipped with two Altex 110 pumps (Altex Scientific Inc., Berkeley, CA, U.S.A.) and Kratos SF 769Z variable wavelength absorbance detector (Kratos Analytical Instruments, Ramsey, NJ, U.S.A.). A Rheodyne 7125 syringe-loading sample injector with a 2-ml loop (Rheodyne Inc., Cotati, CA, U.S.A.) was used in the liquid chromatography. The absorbance of the effluent was continuously monitored at $280 \mathrm{~nm}$ with a chart recorder (Servogor 120, Goerz, Wien, Austria). All the HPLC elutions were performed using a flow rate of $1.0 \mathrm{ml} / \mathrm{min}$. All the samples were first diluted in 
$\mathrm{KH}_{2} \mathrm{PO}_{4}$ buffer, filtered through Millipore filters (pore size $0.45 \mu \mathrm{m}$ ) and then injected into the column.

Measurement of acid and neutral enzyme activities. $\alpha$-Glucosidase activities in the seminal plasma, spermatozoa, reproductive organs and in the fractions after gel filtration, chromatofocussing and anion exchange chromatography were measured with $p$-nitrophenyl- $\alpha$-D-glucopyranoside as substrate by modifying the method of Chapdelaine et al. (1978a). The incubation medium contained $100 \mu 10.1 \mathrm{M}$-sodium acetate, $\mathrm{pH} 4.0$ (acid enzyme activity) or $0.1 \mathrm{M}$-sodium acetate at $\mathrm{pH}$ 7.0 or $2 \mathrm{~mm}$-turanose in $0.1 \mathrm{M}$-sodium acetate at $\mathrm{pH} 7.0$ (neutral enzyme activity), $100 \mu$ l enzyme solution and $100 \mu 11.5 \mathrm{~mm}$ substrate in $50 \%(\mathrm{v} / \mathrm{v})$ ethanol. The incubation was carried out at $37^{\circ} \mathrm{C}$. The reaction was stopped with $500 \mu \mathrm{l} 0 \cdot 1 \mathrm{M}-\mathrm{NaOH}$ and the absorbances were measured with a Gilford Stasar III spectrophotometer at $410 \mathrm{~nm}$.

The protein of the enzyme samples was measured using the method of Lowry, Rosebrough, Farr \& Randall (1951) with bovine serum albumin as the standard. The enzyme activities in the chromatographic fractions are given as absorbances and in the seminal plasma, spermatozoa and reproductive organs as $\mathrm{nmol} / \mathrm{min} \cdot \mathrm{mg} \mathrm{protein}^{-1}$.

Studies on enzyme characteristics. The $\mathrm{pH}$ optima for the enzymes in seminal plasma, seminal vesicle secretion, homogenates of reproductive organs and pooled samples after fractionations were measured in a series of $0.2 \mathrm{M}$-sodium acetate buffers from $\mathrm{pH} 3.0$ to 7.0 , and of $0.2 \mathrm{M}$ $\mathrm{KH}_{2} \mathrm{PO}_{4} / \mathrm{Na}_{2} \mathrm{HPO}_{4}$ buffers from $\mathrm{pH} 7.0$ to 8.0 . The effect of temperature was tested by preincubating the pooled enzyme preparations from HPLC in $0.1 \mathrm{M}$-sodium acetate, $\mathrm{pH} 4.0$ or $7 \cdot 0$, for $15 \mathrm{~min}$ at the temperature indicated. After cooling on ice, $p$-nitrophenyl- $\alpha$-D-glucopyranoside was added, and the enzymes were incubated at $37^{\circ} \mathrm{C}$. The remaining enzyme activity was then assayed and compared with the control preincubated at $37^{\circ} \mathrm{C}$.

The response of the enzyme to various modifiers, Tris and turanose was tested also with pooled activities after HPLC. The modifiers and turanose were dissolved in $0 \cdot 1 \mathrm{M}$-sodium acetate, $\mathrm{pH} 4 \cdot 0$ and $7 \cdot 0$, and the enzyme activity was measured as described earlier. Tris was dissolved in distilled water and the $\mathrm{pH}$ of each Tris concentration was adjusted to 7.0 with $\mathrm{HCl}$, then enzyme and substrate solutions were added and the incubation was carried out at $37^{\circ} \mathrm{C}$. The absorbance readings were converted to percentages using the pooled enzyme without any addition as the control ( $100 \%$ value).

The tentative molecular weights of $\alpha$-glucosidases were estimated from the elution on the Sepharose 6B column with marker proteins according to Andrews (1970).

\section{Results}

Enzyme activity in semen and in reproductive organs

When the hydrolysis of $p$-nitrophenyl- $\alpha$-D-glucopyranoside was analysed at $\mathrm{pH}$ values of 3.0 $8 \cdot 0$, different patterns were obtained with different reproductive tissues and secretions (Text-fig. 2). The testicular homogenate resulted in an acid $(\mathrm{pH} \mathrm{4.0-4.25)}$ and a neutral $(\mathrm{pH} \mathrm{6.5-7.0)}$ area of activity, while the washed ejaculated spermatozoa contained only an acid pH optimum (pH 4.25). The epididymal homogenate of the caput area $\left(\mathrm{E}_{1}\right)$ showed the major activity at the neutral area (pH 6.5) and a minor activity close to $\mathrm{pH} 5.0$. In the secretion recovered from the same segment both acid and neutral pH optima were apparent. Toward the epididymal cauda the activity in the acid $\mathrm{pH}$ area increased relative to the neutral one both in the total homogenate and in the secretion. The activity was also dominant in the acid $\mathrm{pH}$ area in the homogenate of seminal vesicles (not shown).

The relative specific activity of acid ( $\mathrm{pH} 4.0$ ) and neutral ( $\mathrm{pH} 7.0) \alpha$-glucosidase in bull reproductive organs is given in Text-fig. 3 , and the hydrolysis rates of $\alpha$-glucosidases in seminal 

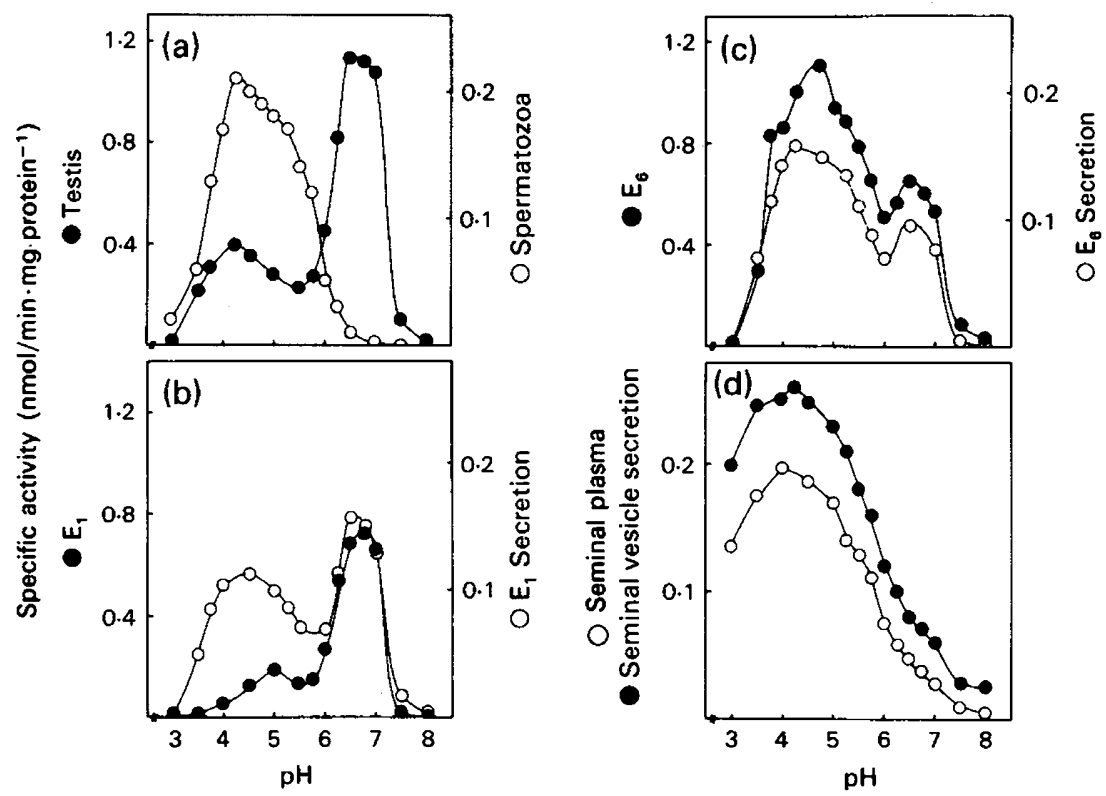

Text-fig. 2. $\mathrm{pH}$ optima of acid and neutral $\alpha$-glucosidases from (a) bull testis and ejaculated spermatozoa; (b) epididymal segment $E_{1}$ and $E_{1}$ secretion; (c) epididymal segment $E_{6}$ and $E_{6}$ secretion; (d) seminal plasma and seminal vesicle secretion.

Table 1. The specific activity of acid ( $\mathrm{pH} \mathrm{4.0)}$ ) and neutral (pH 7.0) $\alpha$-glucosidases in seminal plasma, spermatozoa and seminal vesicle secretion and in epididymal cells, secretions and spermatozoa of different epididymal segments $\left(E_{1}, E_{2}+E_{3}, E_{6}\right)$ in adult bulls

\begin{tabular}{|c|c|c|}
\hline \multirow[b]{2}{*}{ Sample } & \multicolumn{2}{|c|}{$\begin{array}{c}\alpha \text {-Glucosidase activity } \\
(\mathrm{nmol} / \mathrm{min} \cdot \mathrm{mg} \text { protein } \\
-1)\end{array}$} \\
\hline & pH 4.0 & $\mathrm{pH} 7.0$ \\
\hline Seminal plasma & $0.20 \pm 0.03(10)$ & $0.04 \pm 0.01(10)$ \\
\hline Spermatozoa & $0.18 \div 0.06(10)$ & $0.02+0.01(10)$ \\
\hline Seminal vesicle secretion & $0.26 \pm 0.02(3)$ & $0.08 \pm 0.02(3)$ \\
\hline \multicolumn{3}{|l|}{ Epididymal cells } \\
\hline$E_{1}$ & $0.88 \pm 0.17$ & $0.91 \pm 0.12(3)$ \\
\hline $\mathbf{E}_{2}+\mathbf{E}_{3}$ & $2.32 \pm 0.56(3)$ & $1.03 \pm 0.16(3)$ \\
\hline $\mathrm{E}_{6}$ & $1 \cdot 18 \pm 0.12(3)$ & $0.62 \pm 0.11(3)$ \\
\hline \multicolumn{3}{|l|}{ Epididymal secretion } \\
\hline$E_{1}$ & $0.19 \pm 0.09$ & $0.50 \pm 0.05(3)$ \\
\hline$E_{2}+E_{3}$ & $0.19 \pm 0.03(3)$ & $0.25 \pm 0.02(3)$ \\
\hline$E_{6}$ & $0.29 \pm 0.04(3)$ & $0.32 \pm 0.08$ \\
\hline \multicolumn{3}{|l|}{ Epididymal spermatozoa } \\
\hline $\mathrm{E}_{1}$ & $0.66 \pm 0.07(3)$ & $0.71+0.05(3)$ \\
\hline$E_{2}+E_{3}$ & $0.76 \pm 0.22(3)$ & $0.43 \pm 0.08(3)$ \\
\hline$E_{6}$ & $0.47 \pm 0.05$ & $0.56 \pm 0.11(3)$ \\
\hline
\end{tabular}

Values are mean \pm s.d. of duplicate measurements for the number of animals in parentheses. 


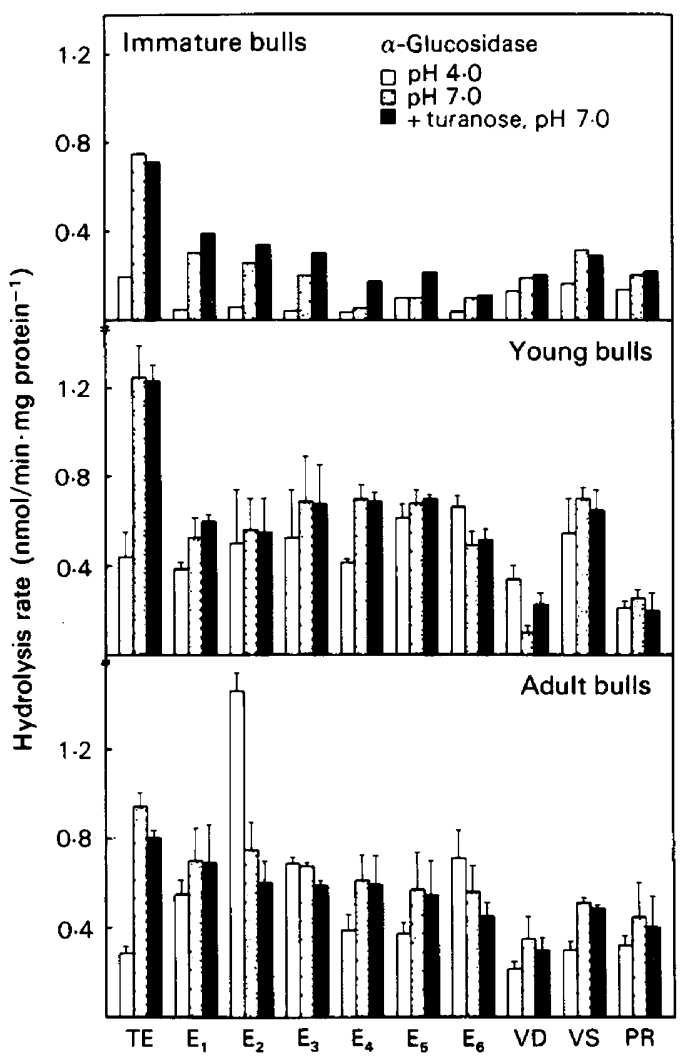

Text-fig. 3. Hydrolysis rate of acid (pH 4.0) and neutral (pH 7.0;0.67 mM-turanose, pH 7.0) $\alpha$ giucosidases in bull testis (TE), different segments of the epididymis $\left(E_{1}-E_{6}\right)$, vas deferens (VD), seminal vesicle (VS) and prostate (PR) of immature (1 month of age), young (5-7 months of age) and adult (about 1 year of age) bulls.

plasma, spermatozoa, seminal vesicle secretion as well as in epididymal tissues, secretions and spermatozoa are shown in Table 1 . In adult bulls the highest level of acid $\alpha$-glucosidase was found in the epididymis, particularly in the caput segments $E_{2}+E_{3}$. The activity of neutral $\alpha$-glucosidase was highest in the testis and in different parts of the epididymis. Turanose $(0.67 \mathrm{mM})$ in the incubation medium did not markedly influence the neutral $\alpha$-glucosidase activity. Seminal plasma, ejaculated spermatozoa and seminal vesicle secretion contained only the acid. enzyme activity. Most of the epididymal acid $\alpha$-glucosidase activity was non-secretory (located in epididymal cells). Part of the neutral activity, on the other hand, seemed to be secretory in the epididymis. Epididymal spermatozoa contained clearly higher acid and neutral $\alpha$-glucosidase levels than did spermatozoa of the ejaculate. Both acid and neutral $\alpha$-glucosidase activities in the epididymis may be hormone-dependent, since the activity levels were significantly higher in the adult epididymis when compared with those in the immature ( 1 month of age) animals. The young bulls (5-7 months of age) had enzyme levels comparable to those of the adult animals. This finding is in agreement with the complete spermatogenesis and presence of spermatozoa in the epididymis found histologically in these bulls.

\section{Sepharose $6 B$ gel filtration}

Gel filtration of bull seminal plasma and seminal vesicle secretion resulted in the appearance of one activity area for acid $\alpha$-glucosidase eluting in fractions $112-138$ (Text-fig 4 ). The homogenates $36: 31 \mathrm{PM}$ 


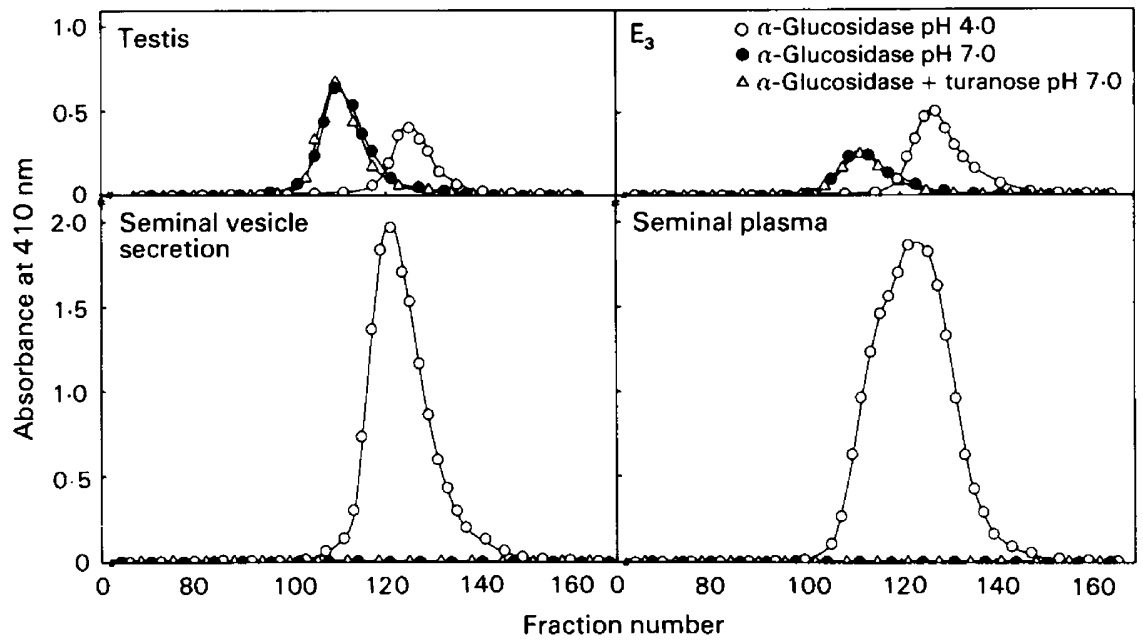

Text-fig. 4. Acid (pH 4.0) and neutral (pH 7.0;0.67 mM-turanose, pH 7.0) $\alpha$-glucosidase activity of bull testis, epididymal segment $\mathrm{E}_{3}$, seminal vesicle secretion and seminal plasma after gel filtration on Sepharose 6B. The hydrolysis was measured in the fractions as described in 'Materials and Methods'. The incubation time was $16 \mathrm{~h}$.

of the testis and different parts of the epididymis contained both an acid and a neutral enzyme activity, which eluted in fractions $120-138$ and 104-118, respectively. The neutral $\alpha$-glucosidase therefore had a higher molecular weight $\left(M_{\mathrm{r}} \sim 400 \times 10^{3}\right)$ than did the acid one $\left(M_{\mathrm{r}} \sim 320 \times 10^{3}\right)$.

\section{Chromatofocussing}

Chromatofocussing of bull seminal plasma (Text-fig. 5) resulted in the appearance of two activity areas for acid $\alpha$-glucosidase (CF-3 and CF-4). CF-3 had a pI value between 4.5 and 4.0 and

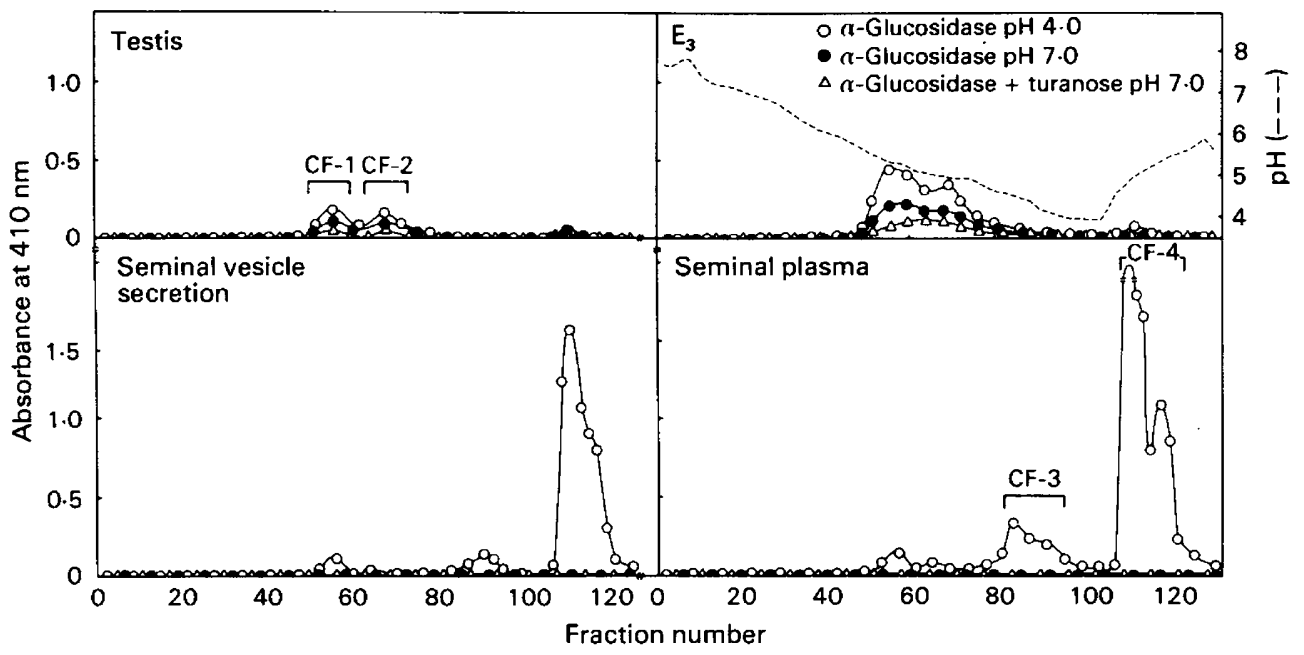

Text-fig. 5. Acid (pH 4.0) and neutral (pH 7.0;0.67 mM-turanose, $\mathrm{pH} 7.0$ ) $\alpha$-glucosidase activity in chromatofocussing of bull testis, epididymal segment $\mathbf{E}_{3}$, seminal vesicle secretion and seminal plasma. The hydrolysis of acid and neutral $\alpha$-glucosidases was measured as indicated in

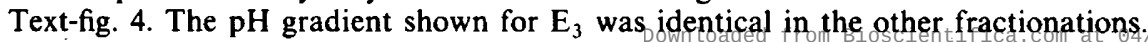


$\mathrm{CF}-4$ eluted always with the $\mathrm{NaCl}$ gradient (0-0.5 M). Seminal vesicle secretion was found to be the source of these acid secretory enzyme activities in seminal plasma. The activity peaks CF-1 (pI 5.5$5 \cdot 2$ ) and CF-2 (pI 5.1-4.7) (containing acid and neutral $\alpha$-glucosidases) were present in the testis and in different parts of the epididymis.

\section{Anion exchange chromatography}

After anion exchange chromatography with HPLC, acid $\alpha$-glucosidase activity of seminal plasma was recovered in two fractions (H-5, fractions 16-26 and H-6, fractions 31-46) (Text-fig. 6). Seminal vesicle secretion also showed the corresponding activities. The testicular and epididymal homogenates contained two acid and two neutral $\alpha$-glucosidases, eluting in fractions $12-19(\mathrm{H}-1)$, 21-32 (H-2), 40-46 (H-3) and 78-84 (H-4), respectively.

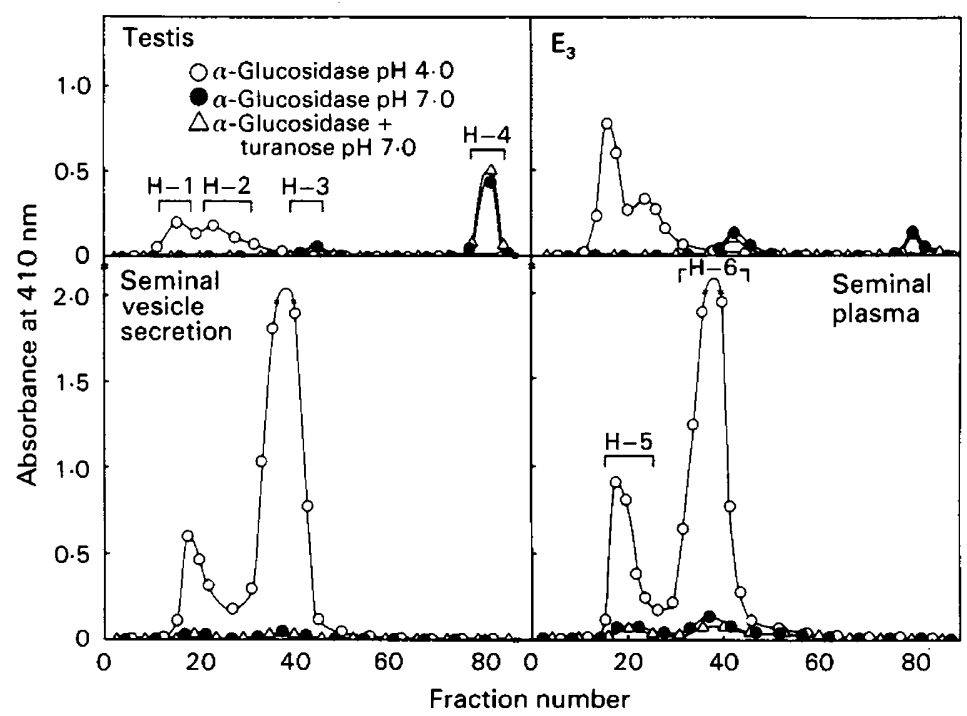

Text-fig. 6. Acid (pH 4.0) and neutral (pH 7.0;0.67 mM-turanose, pH 7.0) $\alpha$-glucosidase activity after anion exchange chromatography in HPLC (Mono Q) of bull testis, epididymal segment $E_{3}$, seminal vesicle secretion and seminal plasma. The hydrolysis of acid and neutral $\alpha-$ glucosidases was measured as indicated in Text-fig. 4.

\section{Biochemical characteristics}

Effect of $\mathrm{pH}$. The acid $\alpha$-glucosidase peaks pooled after HPLC of bull seminal plasma $(\mathrm{H}-5, \mathrm{H}$ 6), seminal vesicle secretion $(\mathrm{H}-5, \mathrm{H}-6)$, testis $(\mathrm{H}-1, \mathrm{H}-2)$ and epididymis $(\mathrm{H}-1, \mathrm{H}-2)$ had an optimum at $\mathrm{pH} 3 \cdot 75-4 \cdot 5$. The neutral enzyme peaks of testis and epididymis after gel filtration or HPLC (H-3, H-4) were optimally active at $\mathrm{pH} \mathrm{6 \cdot 5-7 \cdot 0.}$

Effect of temperature. The effect of heat treatment on the pooled enzyme preparations $\mathrm{H}-1-\mathrm{H}-6$ after HPLC is seen in Text-fig. 7. The neutral isoenzymes $(\mathrm{H}-3, \mathrm{H}-4)$ seemed to be highly sensitive to thermal inhibition, while the acid enzymes $(\mathrm{H}-1, \mathrm{H}-2, \mathrm{H}-5, \mathrm{H}-6)$ were more resistant to the treatment and about $80 \%$ of activity was still present after a 15 -min preincubation at $65^{\circ} \mathrm{C}$.

Modifier characteristics. The effects of the various modifiers were tested on the pooled $\alpha$ glucosidase activities after $\mathrm{HPLC}(\mathrm{H}-1, \mathrm{H}-2, \mathrm{H}-5$ and $\mathrm{H}-6$ at $\mathrm{pH} 4 \cdot 0 ; \mathrm{H}-3$ and $\mathrm{H}-4$ at $\mathrm{pH} 7 \cdot 0)$. Of the cations tested $\mathrm{Hg}^{2+}(1 \mathrm{mM})$ inhibited strongly the acid and neutral $\alpha$-glucosidases, and $\mathrm{Cd}^{2+}, \mathrm{Co}^{2+}$, $\mathrm{Cu}^{2+}, \mathrm{Mg}^{2+}, \mathrm{Ni}^{2+}, \mathrm{Zn}^{2+}$, EDTA and IAA inhibited the neutral $\alpha$-glucosidase isoenzymes but had 


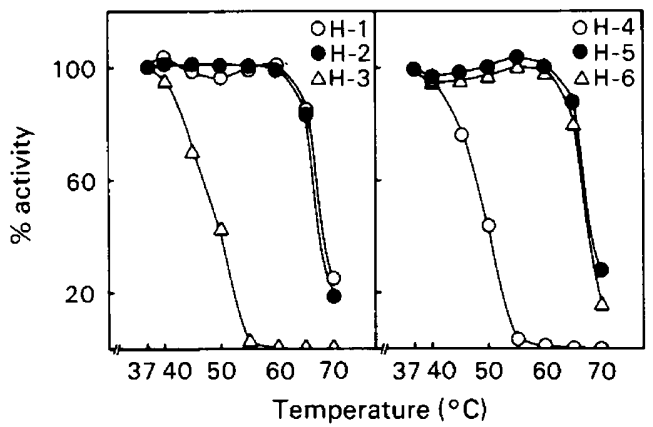

Text-fig. 7. Effect of temperature on the pooled acid and neutral $\alpha$-glucosidase activities after anion exchange chromatography in HPLC (Mono Q) of bull testis and epididymis $(\mathrm{H}-1, \mathrm{H}-2$, $\mathrm{H}-3, \mathrm{H}-4)$ and of seminal plasma and seminal vesicle secretion $(\mathrm{H}-5, \mathrm{H}-6)$. The incubations were carried out in $0 \cdot 1 \mathrm{M}$-sodium acetate, $\mathrm{pH} 4 \cdot 0(\mathrm{H}-1, \mathrm{H}-2, \mathrm{H}-5, \mathrm{H}-6)$ or $\mathrm{pH} 7 \cdot 0(\mathrm{H}-3, \mathrm{H}-4)$. The results are given as percentages of the uninhibited control values for the appropriate activities.

no effect on acid $\alpha$-glucosidases. However, $\mathrm{KCl}$ had a weak activating effect on acid $\alpha$-glucosidase preparations, but inhibited the neutral preparations (at $\mathrm{KCl}$ concentrations $>10 \mathrm{mM}$ ).

Inhibition by Tris-buffer and turanose. Turanose (at concentration greater than $0 \cdot 1 \mathrm{~mm}$ ) was inhibitory for the acid enzyme activities. The neutral enzymes were inhibited by 1-100 mM-Tris buffer, $\mathrm{pH} 7 \cdot 0$, and 1-100 mM-turanose.

\section{Discussion}

Seminal plasma is formed by the secretory activity of many reproductive organs. To determine the origins of seminal enzymes, e.g. $\alpha$-glucosidases, would require access to pure secretory fluid from each of the organs. In the bull the collection of pure secretion from the seminal vesicles causes no problems, but isolation of the secretory fluid from different segments of the epididymis, and the prostate and Cowper's glands would require sophisticated cannulations of these organs or their selective extirpation and subsequent seminal plasma collection. In this study such an approach was not possible. We were well aware of the eventual shortcomings in harvesting pure secretory fluid from pieces of epididymal segments, but we were able to obtain consistent results in repeated experiments using gentle manipulation of tissue in isotonic media. These observations could also be correlated to findings obtained with total homogenates of the respective segments.

The results of this study clearly demonstrated that both acid and neutral $\alpha$-glucosidases are present in bull reproductive tissues. The highest specific activity of acid $\alpha$-glucosidase was found in the epididymis and particularly in its caput region. The activity of neutral $\alpha$-glucosidase was highest in the testis and in different parts of the epididymis. Ejaculated spermatozoa, seminal vesicle secretion and seminal plasma had only the acid enzyme activity. Paquin et al. (1984) have shown that the neutral $\alpha$-glucosidase in human seminal plasma is of epididymal origin. Our studies with bull reproductive organs clearly demonstrated that in the bull epididymis the $\alpha$-glucosidase activity seems to be tissue-bound and only a minor part of the activity was found in the epididymal secretion. In addition, this secretory enzyme was not found in the seminal plasma and therefore it may have a local function in the bull epididymis.

The activities of the acid and neutral $\alpha$-glucosidases were higher in the epididymis of mature than of immature animals. This suggests that the enzymes are associated with the functional state of this organ and are probably also hormone-controlled as has been postulated by Grandmont et al. (1983) for the $\alpha$-glucosidase activities in the rat reproductive system. Part of the acid $\alpha$-glucosidase can be due to the activity in the cytoplasmic droplets (Garbers, Wakabayashi \& Reed, 1970) and 
the reduction in its activity from the caput to cauda epididymidis and from epididymal to ejaculated spermatozoa could be due to gradual disappearance of the droplets. These findings are in agreement with the results of Bhattacharyya \& Nag Das (1983) on goat spermatozoa.

In the gel filtration with Sepharose 6B, the neutral $\alpha$-glucosidase eluted earlier from the column than did the acid $\alpha$-glucosidase, thus demonstrating a higher molecular weight for the neutral enzyme. Previously, gel filtration on Sephadex G-100 has been used in the purification of $\alpha$ glucosidase (Dissous, Ansart, Cheron \& Krembel, 1981; Martiniuk \& Hirschhorn, 1981). In this medium the elution is not consistent with the molecular weight of the enzyme because of its specific binding to the cross-linked dextran. Martiniuk \& Hirschhorn (1981) showed that human neutral $\alpha$ glucosidase had a higher molecular weight after gel filtration on Sephacryl S-200 or Bio-Gel P-300 $\left(350 \times 10^{3}\right)$ than after chromatography on Sephadex G-100 or G-200 $\left(160 \times 10^{3}\right)$. A value of $288 \times$ $10^{3}$ was obtained for glucosidase II (neutral enzyme) of rat liver endoplasmic reticulum using gel filtration on Sephacryl S-300 (Burns \& Touster, 1982), and a value of $280 \times 10^{3}$ for neutral $\alpha$ glucosidase from horse kidney using gel filtration on Ultrogel AcA 2/2 (Giudicelli, Emiliozzi, Vannier, de Burlet \& Sudaka, 1980).

The fractionation of bull seminal plasma with chromatofocussing and anion exchange chromatography resulted in the appearance of two acid $\alpha$-glucosidase activities. The seminal vesicle secretion showed the same activities and thus forms the major secretory source of acid $\alpha$ glucosidase in the seminal plasma. In anion exchange chromatography the testicular and epididymal homogenates contained two acid and two neutral $\alpha$-glucosidases, which were not coeluting with the secretory acid $\alpha$-glucosidase of seminal plasma and seminal vesicle secretion.

In chromatofocussing, two activity areas were obtained for each of the acid and neutral enzyme activities of the testis and epididymis with higher pI values than for the enzyme activities of seminal plasma and seminal vesicle secretion. The multiple forms of the acid secretory enzyme in the seminal plasma and seminal vesicle secretion as well as of the tissue-bound acid and neutral $\alpha$ glucosidases may be due to minor structural differences, which are not reflected in their molecular weight estimation by gel filtration. Multiple molecular forms of neutral $\alpha$-glucosidase in male reproductive tissues and in other organs have been reported previously. Chapdelaine et al. (1978b) showed with ion exchange chromatography on DEAE-Sephadex that human seminal plasma and cytosols of human reproductive organs contained three different neutral $\alpha$-glucosidase activities (A, $B$ and $C$ ). Of these peaks $B$ and $C$ occurred in the seminal plasma, peaks $A$ and $B$ in the epididymis and the prostate and peak $A$ in the testis. Martiniuk \& Hirschhorn (1981), on the other hand, showed that two neutral $\alpha$-glucosidases (called AB and C) from human tissues had isoelectric points of 6.1 and 5.5 , respectively. In the human liver several forms of acid $\alpha$-glucosidase with pI values between 4.4 and 4.7 were also demonstrated by Murray, Brown \& Brown (1978). At least partly these differences can be ascribed to modifications in the carbohydrate side-chains of their glycoprotein structure. These isoenzymes may also have different subcellular locations and functional activities (Rosenfeld, 1975; Murray et al., 1978).

The acid $\alpha$-glucosidase from bull seminal plasma, spermatozoa and reproductive organs had a $\mathrm{pH}$ optimum at 3.75-4.5 and the neutral enzyme from the reproductive organs had its maximum activity at about pH 6.5-7.0. Human seminal plasma $\alpha$-glucosidase is neutral, pH optimum 5.5-6.8 (Paquin et al., 1984), while in ram seminal plasma the optimum of $\alpha$-glucosidase varies between $\mathrm{pH}$ 3.5 and 4.0 (Besancon et al., 1983). The rat reproductive system contains both acid (pH optimum $3.8-4.5$ ) and neutral (pH optimum 5.8-7.0) $\alpha$-glucosidase activities (Grandmont et al., 1983).

The neutral $\alpha$-glucosidases from bull reproductive organs were very sensitive to heat inhibition; they were almost totally inactivated at $55^{\circ} \mathrm{C}$. The acid isoenzymes, however, were quite heat-stable up to $60^{\circ} \mathrm{C}$ after which they became progressively inactivated. Tris is a known inhibitor of acid $\alpha$ glucosidase activity (Bruni, Auricchio \& Covelli, 1969; Chapdelaine et al., 1978a), but in our study the neutral $\alpha$-glucosidase from bull reproductive organs was also inhibited by Tris at $\mathrm{pH} 7 \cdot 0$. The disaccharide turanose has been clearly shown to inhibit the acid lysosomal $\alpha$-glucosidase (Bruni et al., 1969; Besancon et al., 1983; Chambers \& Williams, 1983). In our study, turanose inhibited the 
acid and neutral $\alpha$-glucosidases of bull reproductive organs. $\mathrm{KCl}$, however, caused a slight activation of acid $\alpha$-glucosidase, but inhibited the neutral enzyme at higher concentrations. $\mathrm{KCl}$ and turanose have been used as effectors in the selective determination of neutral and acid $\alpha$ glucosidase from human urine (Kochmann, Kochmann, Pape, Blank \& Baumann, 1983; Pape, Kochmann, Kochmann, Blank \& Baumann, 1983), but this does not seem applicable for bull reproductive tissues.

Based on the present findings we can conclude that, in the bull, acid $\alpha$-glucosidase of the seminal plasma is a secretory product of the seminal vesicles, while the neutral enzyme(s) are mostly intracellular or locally active in other parts of the reproductive organs and do not contribute to the formation of the seminal plasma. The secreted acid enzyme in the seminal vesicles and the neutral enzyme (s) in other reproductive tissues seem to be under hormonal control. The former enzyme in the seminal plasma can be regarded as a marker for the activity of the seminal vesicles. Further studies with castrated and vasectomized bulls would give additional information in this respect. The role of the enzyme in the hydrolysis of oligo- and polysaccharides in the seminal plasma or in the sperm plasma membrane remains to be explored. The acid and neutral enzyme in the epididymis and other reproductive tissues, on the other hand, could function in the destruction of cytoplasmic droplets of spermatozoa or in the digestion of absorbed polysaccharides and glycoproteins as well as in the processing of glycoproteins synthesized by these organs.

We thank Dr Eero Remes from AI Station of East and Middle Finland and Dr Veikko Rosendahl from Lihakunta Abattoir for organizing the supply of bull semen and reproductive organ samples, and Miss Eija Kettunen, Miss Arja Venäläinen and Mrs Rauni Peltonen for their skilful technical and secretarial assistance. This work was supported by The Ministry of Agriculture and Forestry of Finland and The North-Savo Fund of The Finnish Cultural Foundation.

\section{References}

Andrews, P. (1970) Estimation of molecular size and molecular weights of biological compounds by gel filtration. In Methods of Biochemical Analysis, Vol. 18, pp. 1-450. Ed. D. Glick. Interscience, New York.

Besancon, J., Chapdelaine, P., Tremblay, R.R. \& Lemay, J.P. (1983) Comparative study of $\alpha$-glucosidase activities in blood and seminal plasma of rams. Comp. Biochem. Physiol. 74B, 529-532.

Bhattacharyya, A. \& Nag Das, S.K. (1983) Changes in some hydrolytic enzymes in spermatozoa during maturation. IRCS Med. Sci. 11, 1089-1090.

Bruni, C.B., Auricchio, F. \& Covelli, I. (1969) Acid $\alpha \cdot D$ glucosidase glucohydrolase from cattle liver. Isolation and properties. J. biol. Chem. 244, 4735-4742.

Bruni, C.B., Sica, V., Auricchio, F. \& Covelli, I. (1970) Further kinetic and structural characterization of the lysosomal $\alpha$-D-glucoside glucohydrolase from cattle liver. Biochim. Biophys. Acta. 212, 470-477.

Burns, D.M. \& Touster, O. (1982) Purification and characterization of glucosidase II, an endoplasmic reticulum hydrolase involved in glycoprotein biosynthesis. J. biol. Chem. 257, 9991-10000.

Chambers, J.P. \& Williams, J.C. (1983) Acid alphaglucosidase from human heart. Enzyme 29, 109-119.

Chapdelaine, P., Tremblay, R.R. \& Dubé, J.Y. (1978a) pNitrophenyl- $\alpha-D$-glucopyranoside as substrate for measurement of maltase activity in human semen. Clin. Chem. 24, 208-211.
Chapdelaine, P., Tremblay, R.R., Dubé, J.Y., St-Yves, C. \& Mailhot, J. (1978b) Origin of maltase and variations in infertile men. Archs Androl. 1, 61-68.

Chapdelaine, P., Tremblay, R.R. \& Dubé, J.Y. (1979) Purification and properties of neutral $\alpha-1,4$ glucosidase from human seminal plasma. Archs Androl. 3, 153-161.

Dissous, C., Ansart, J.F., Cheron, A. \& Krembel, J. (1981) Purification of rat liver lysosomal $\alpha$-glucosidase. Analyt. Biochem. 116, 35-39.

Garbers, D.L., Wakabayashi, T. \& Reed, P.W. (1970) Enzyme profile of the cytoplasmic droplet from bovine epididymal spermatozoa. Biol. Reprod. 3, 327-337.

Giudicelli, J., Emiliozzi, R., Vannier, C., de Burlet, G. \& Sudaka, P. (1980) Purification by affinity chromatography and characterization of a neutral $\alpha$-glucosidase from horse kidney. Biochim. Biophys. Acta 612, 85-96.

Grandmont, A.-M., Chapdelaine, P. \& Tremblay, R.R. (1983) Presence of $\alpha$-glucosidases in the male reproductive system of the rat and hormonal influences. Can. J. Biochem. Cell Biol. 61, 764-769.

Guerin, J.-F., Rollet, J., Perrin, P., Menezo, Y., Orgiazzi, A. \& Czyba, J.-C. (1981) Enzymes in the seminal plasma from azoospermic men: correlation with the origin of their azoospermia. Fert. Steril. 36, 368-372.

Gunaga, K.P., Sheth, A.R. \& Rao, S.S. (1967) Maltase 
activity in the accessory reproductive organs of rats \& mice. Indian J. exp. Biol. 5, 141-143.

Gunaga, K.P., Sheth, A.R., Rao, S.S. \& Pardanani, D.S. (1971) Effect of testosterone therapy on the constituents of human seminal plasma. J. Urol. 106, 920-923.

Kochmann, G., Kochmann, R., Pape, W., Blank, M. \& Baumann, K. (1983) Selective determination of the activities of neutral and acid $\alpha$-glucosidase using discontinuous assays. J. clin. Chem. clin. Biochem. 21, 503-509.

Lowry, O.H., Rosebrough, N.J., Farr, A.L. \& Randall, R.J. (1951) Protein measurement with the Folin phenol reagent. J. biol. Chem. 193, 265-275.

Martiniuk, F. \& Hirschhorn, R. (1981) Characterization of neutral isoenzymes of human $\alpha$-glucosidase. Differences in substrate specificity, molecular weight and electrophoretic mobility. Biochim. Biophys. Acta 658, 248-261.

Michael, J.M. \& Kornfeld, S. (1980) Partial purification and characterization of the glucosidases involved in the processing of asparagine-linked oligosaccharides. Archs Biochem. Biophys. 199, 249-258.

Murray, A.K., Brown, B.I. \& Brown, D.H. (1978) The molecular heterogeneity of purified human liver lysosomal $\alpha$-glucosidase (acid $\alpha$-glucosidase). Archs Biochem. Biophys. 185, 511-524.

Nicander, L. (1958) Studies on the regional histology and cytochemistry of the ductus epididymidis in stallions, rams and bulls. Acta morph. neerl. scand. 1, 337-362.
Pape, W., Kochmann, R., Kochmann, G., Blank, M. \& Baumann, K. (1983) Excretion of neutral $\alpha$-glucosidase, determined with a continuous assay, and of acid $\alpha$-glucosidase in the urine of human reference subjects. J. clin. Chem. clin. Biochem. 21, 511-517.

Paquin, R., Chapdelaine, P., Dubé, J.Y.\& Tremblay, R.R. (1984) Similar biochemical properties of human seminal plasma and epididymal $\alpha-1,4$-glucosidase. $J$. Androl. 5, 277-282.

Rivas, F., Velázquez, A., Díaz, M., Olivares, N., Vaca, G. \& Cantú, J.M. (1981) $\alpha, 1-4$ Glucosidase activity in human seminal plasma from normal, vasectomized, and subfertile men. Archs Androl. 7, 319-321.

Rosenfeld, E.L. (1975) Alpha-glucosidases (gammaamylases) in human and animal organisms. Path. Biol. 23, 71-84.

Sheth, A.R. \& Rao, S.S. (1962) Maltase activity in human semen. Experientia 18, 370-372.

Torres, H.N. \& Olavarria, J.M. (1964) Liver $\alpha$-glucosidases. J. biol. Chem. 239, 2427-2434.

Tremblay, R.R., Chapdelaine, P. \& Dubé, J.Y. (1982a) Neutral $\alpha$-1,4-glucosidase in human seminal plasma : molecular forms in varicocele and after vasectomy. Fert. Steril. 38, 344-348.

Tremblay, R.R., Chapdelaine, P., Roy, R. \& Thabet, M. (1982b) Correlation between L-carnitine and $\alpha-1,4-$ glucosidase activity in the semen of normal, infertile and vasectomized men. Infertility 5, 61-70.

Received 20 November 1984 